\title{
MULTI-PERSON SELECTION OF THE BEST WIND TURBINE BASED ON THE MULTI-CRITERIA INTEGRATED ADDITIVE-MULTIPLICATIVE UTILITY FUNCTION
}

\author{
Vygantas BAGOČIUS ${ }^{\mathrm{a}, \mathrm{b}}$, Edmundas Kazimieras ZAVADSKAS ${ }^{\mathrm{a}}$, Zenonas TURSKIS $^{\mathrm{a}}$ \\ ${ }^{a}$ Department of Construction Technology and Management, Vilnius Gediminas Technical University, \\ Saulètekio al. 11, 10223 Vilnius, Lithuania \\ ${ }^{b}$ Civil Engineering Department, Klaipèda University, Bijūnu g. 17, 91225 Klaipèda \\ Received 17 Oct 2013; accepted 24 Apr 2014
}

\begin{abstract}
Energy generation and savings is a vital problem for the social and economic development of a modern world. The construction of wind farms is a challenge of crucial importance to Lithuania. Offshore wind farms are one of the possibilities of the multiple use of marine space. Wind energy industry has become the fastest growing renewable energy in the world. An offshore wind farm is considered one of the most promising sources of green energy towards meeting the EU targets for 2020 and 2050 . They provide long-term green energy production. The major purpose of this study is the selection and ranking of the feasible location areas of wind farms and assessing the types of wind turbines in the Baltic Sea offshore area. Multi-criteria decision making methods represent a robust and flexible tool investigating and assessing possible discrete alternatives evaluated applying the aggregated WSM and WPM method namely WASPAS. The following criteria such as the nominal power of the wind turbine, max power generated in the area, the amount of energy per year generated in the area, investments and $\mathrm{CO}_{2}$ emissions have been taken into consideration.
\end{abstract}

Keywords: offshore, wind turbine, foundations, MCDM, WASPAS.

Reference to this paper should be made as follows: Bagočius, V.; Zavadskas, E. K.; Turskis, Z. 2014. Multi-person selection of the best wind turbine based on the multi-criteria integrated additive-multiplicative utility function, Journal of Civil Engineering and Management 20(4): 590-599. http://dx.doi.org/10.3846/13923730.2014.932836

\section{Introduction}

Climate change and global warming are the most critical issues facing the world today (Hessami et al. 2011). World politicians of the highest rank speak that the energy production system is to be changed; otherwise, our planet will face catastrophic consequences. Green energy (wind, sun, water and other resources), which, for some time, has been considered to be only an enthusiastic invention, is getting more and more attractive for big business investments.

The current concerns about climate change relate strongly to past technological developments that have fundamentally changed the structure of the energy sector by making possible the diffusion of new and less costly technologies (Soderholm, Pettersson 2011). The rapid development of wind energy technology has made it to be the most promising alternative to conventional energy systems in recent years (Lee et al. 2009).

Wind energy is presented as one of the strategies for tackling global warming and accomplishing the Kyoto Protocol (Gamboa, Munda 2007). Recently, wind energy has started to be valued as the national wealth of each country just like the resources of organic fuel (oil, gas). These sources of energy, unlike organic fuel, are inex- haustible. Employing them ensures great ecological, social and political advantages, and in the nearest future, will undoubtedly bring economic benefits.

Over the past decade, many countries have invested heavily in wind power, and the current energy policies imply that there is a lot more investment to come in (Green, Vasilakos 2011). Most of the existing wind power plants are constructed on land while some countries (first of all in Europe) have started to invest into developing sea wind power parks. Offshore wind energy generation is the fastest growing source of renewable energy in the world (Singh et al. 2010).

\section{Description of offshore wind power turbines}

The problems of sustainable energy generation are complicated. Modern technologies should be defined applying a multiple criteria set. The criteria describing alternatives have different measurement units and optimization directions.

Martin et al. (2013) applied the TOPSIS (Technique for Order Preference by Similarity to Ideal Solution) method for assessing the conceptual design process of floating offshore wind turbine support structures. Collu et al. (2012) investigated the design space of a floating 
support structure for an offshore vertical axis wind turbine. The alternatives are ranked based on the TOPSIS method. Lozano-Minguez et al. (2011) provided a systemic assessment of the selection of the most preferable, among different configurations, offshore support structures taking into consideration several criteria through TOPSIS for benchmarking candidate options. Lee et al. (2012) presented an integrated MCDM model incorporating Interpretive Structural Modelling (ISM), the Fuzzy Analytic Network Process (FANP) and the VIKOR method. Kaya and Kahraman (2010) applied an integrated fuzzy VIKOR and AHP method to determine the best renewable energy alternative for Istanbul. Van Haaren and Fthenakis (2011) proposed a spatial multi-criteria methodology implemented in New York State, and the results were compared with the locations of the existing wind turbine farms and based on multi-criteria analysis. Khan and Rehman (2012) presented study on the efficient design of wind farms in Saudi Arabia. The conducted analysis has been based on a fuzzy logic decision making approach.

While onshore wind is developing by leaps and bounds, in the meantime, offshore wind has also attracted people's attention in recent years. As generally known, wind energy is clean and inexpensive, but space for turbines is becoming scarce, which makes offshore wind an attractive choice (Leung, Yang 2012).

New investment in the capacity of offshore wind generation has shown a remarkable increase. The total offshore installed capacity in Europe has increased from under $50 \mathrm{MW}$ in 2000 to about $1471 \mathrm{MW}$ by the end of 2010 thus translating to an average annual rate of growth in about $50 \%$ per year (Green, Vasilakos 2011).

Conducting the research and development of offshore wind power began in the ' 70 s of the last century. After more than 30 years of progress, offshore wind power technology is becoming more and more mature and has entered the stage of large-scale development (Zhixin et al. 2009).

Europe has always been the leader in offshore wind technology. Looking back on the history of offshore wind, it is necessary to mention Denmark that is not only the second highest contributor to offshore wind in Europe but also a pioneer in this field. One should never forget that the United Kingdom is the leader in producing European wind energy.

Despite its growth, the current share of offshore capacity remains relatively low when compared to that operating onshore (only over $2 \%$ of total wind capacity for EU-27) (Green, Vasilakos 2011). It is expected that in 2020, European offshore wind power capacity could reach the one-third of electricity demand for Europe) (Zhixin et al. 2009).

Despite many advantages, sea energy production presents plenty of challenges that should be overcome in order to ensure more successful development of sea wind power plants. First of all, the cost of constructing an offshore wind farm is 1.5-2 times greater than that of the onshore one, as towers, foundations, underwater cabling and installation offshore are more difficult and expensive
(Offshore Wind Collaborative Organizing 2005). Since the offshore wind farm is far away from the shore, maintenance and repair are also more challenging due to difficulty in accessing the site. What is more, the need for crane vessels in repair makes it 5-10 times more expensive than onshore repair (Van Bussel, Zaaijer 2001).

The operation of wind power plants depends on two most important components: wind turbines and wind. A rotor of a wind turbine consists of blades and a rotor hub. The requirements set for the blades include the maximal diameter of the rotor and the height of its axe as well as aerodynamic efficiency to get as much energy from the wind as possible, low weight, simple production technology, sufficient resistance to mechanical loads and weather impact, durability (Gipe 2004).

Previous investigations have shown that for an efficient wind farm, operation distance between adjacent wind turbines should make 5-10 diameters of the rotor (Maeda et al. 2004). However, in the case of a possibility of positioning wind farms considering wind direction, a distance between wind power plants may be reduced (Markevičius et al. 2007).

Wind velocity is the most important parameter for evaluating wind energy resources. Any choice for designing wind turbines must be based on the average wind velocity at the selected site for constructing wind turbines (Katinas et al. 2009).

The wind and its speed in the industry of wind power plants is the most important feature, because it determines where the wind power park is going to be located, what size it will have to fit and whether it is going to be constructed in this place at all. The amount of energy produced by a wind turbine during a long period of time may be calculated rather precisely because the average wind speed and direction at a certain place change insignificantly.

Regular measurements of wind velocities and directions have been performed in Lithuania since 1945. The measurements are performed typically at a height of $10 \mathrm{~m}$ above the ground level every $3 \mathrm{~h}$. All readings are averages over the specified periods of time. Monthly and annual averages are also determined (Katinas et al. 2009).

An onshore wind farm can be typically utilized about 2000-3000 h per year while an offshore farm normally achieves a utilization rate of approximately 3000 $4000 \mathrm{~h}$ annually. In addition, the environmental costs of offshore installations are overall lower than those typically experienced at onshore farms (Soderholm, Pettersson 2011).

Offshore winds are less turbulent (because the ocean is flat relative to onshore topography), and they tend to flow at higher speeds than onshore winds thus allowing turbines to produce more electricity. Because the energy produced from the wind is directly proportional to the cube of wind speed, increased wind speeds of only a few miles per hour can produce a significantly larger amount of electricity. For instance, a turbine at a site with an average wind speed of $26 \mathrm{~km} / \mathrm{h}$ would produce $50 \%$ more electricity than that at a site with the same turbine and an average wind speed of $22 \mathrm{~km} / \mathrm{h}$ (Kurian et al. 2009). 
As regards big wind turbines, steel pipes narrowing towards the top are used for the tower, although other structures are also suitable for low power wind turbines.

In general, the support of the wind power plant at sea is influenced by (Structural Engineers Club 2014):

-wind;

- wave and current loads;

-hydrodynamic and hydrostatic water pressure;

- own weight;

- operational load;

-ice;

- fluctuations in temperature;

- forces on the top of the body that appear from the movement of the blades;

- other impacts of ships, rust, deposits, etc.

For designing wind power plants, one may not take into consideration some of the loads.

One of the most important features of offshore wind generators are the selection of foundations. The foundations of a tower are different when constructed in the sea and on land. Wind pressure forces act on the wind turbine. For example, if the diameter of the rotor of the wind turbine reaches $100 \mathrm{~m}$, under the wind speed of $25 \mathrm{~m} / \mathrm{s}$, the air mass equal to $470 \mathrm{t} / \mathrm{s}$ goes through the rotor. The turbine tower itself has to stand wind pressure at wind speed equal to $50 \mathrm{~m} / \mathrm{s}$. Therefore, the resistance of the basement must meet high demands.

The price of constructing the basement of the wind power plant and the foundations themselves differ a lot depending on whether they are built in the sea or on land. For a typical onshore wind power station, the cost of foundations normally represents $4-6$ percent of the total investment costs (Lemming et al. 2008). Offshore foundations constitute a significant fraction of the overall installed cost that varies between $15 \%$ and $40 \%$ (Houlsby, Byrne 2000). Higher costs can also be explained by the fact that, so far, no well-developed supply industry for installation work offshore has been offered, and that during recent years, offshore wind power industry has been forced to compete with more established fossil fuel industry for these installation services (Sovacool et al. 2008).
In the case of offshore wind power development, water depth considerably affects the economics of the wind power project when establishing the offshore foundations the type of which is dependent on water depth and soil conditions, etc. (Kim et al. 2013).

The main types of the foundations of wind power plants in the sea are discussed below:

- Gravity base structure (Fig. 1a) foundations are typically used at sites where the installation of piles in the underlying seabed is difficult, such as on a hard rock ledge in relatively shallow waters (Malhotra 2010). The maximum depth achieved applying this system can reach $10 \mathrm{~m}$. Concrete is the only material used for producing it (Singh et al. 2010).

- Monopole (Fig. 1b) covers a simple design and consists of a steel pipe pile (Carey 2002). The diameter varies from 6 to $8 \mathrm{~m}$. (Singh et al. 2010) and wall thickness as much as $150 \mathrm{~mm}$ (Carey 2002). Depth achieved by the monopole is in the range of 25 to $30 \mathrm{~m}$. It is a steel tabular structure the manufacturing of which is simple and quick (Singh et al. 2010). Monopoles are flexible (Carey 2002).

-Tripod (Fig. 1c) has a structure that is considered to be relatively lightweight. Under the central steel column, which is below the turbine, there is a steel frame that transfers forces from the tower into three steel piles installed at each leg position to anchor the tripod to the seabed. The three piles are driven 10$20 \mathrm{~m}$ into the seabed. The tripod can also be installed using suction buckets. The foundations of the tripod have good stability and overall stiffness. The tripod support structure is pre-assembled in an onshore construction yard. The entire structure is placed on a suitable vessel such as a barge and transported to the offshore location where it is slowly lowered onto the seabed ensuring it is entirely level. When the piles are at the required depth, a connection between the top of the pile and the pile sleeve is made by filling the annulus with grout or by means of a swaged connection (Four C Offshore 2013b).

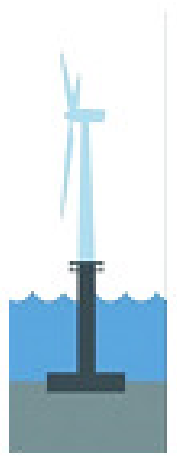

(a)

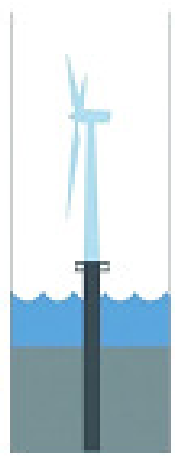

(b)

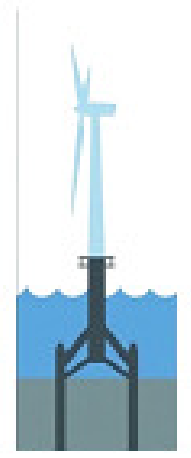

(c)

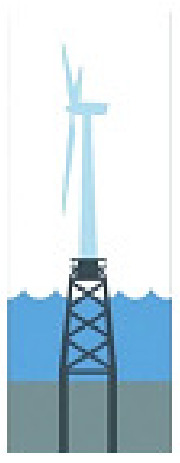

(d)

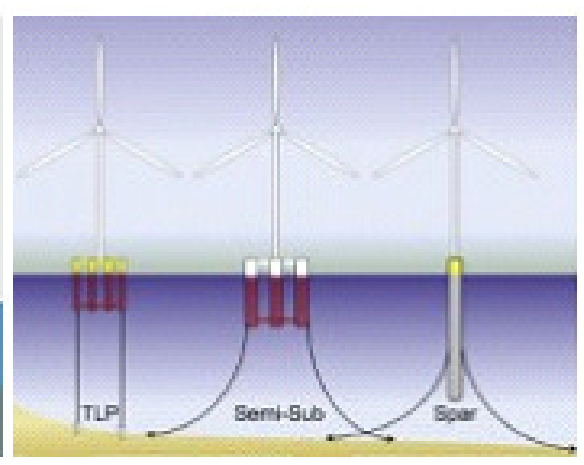

(e)

Fig. 1. The types of the foundations of the offshore wind turbine: $a$ - gravity base structure, $b$ - monopole, $\mathrm{c}-$ tripod, $\mathrm{d}-$ jacket structures, e - floating platform (First for Technology and Innovation 2013) 
- Jacket structures (Fig. 1d) contain many variants of the three or four-legged jacket/lattice structure typically consisting of corner piles interconnected with bracings with up to $2 \mathrm{~m}$ in diameter. These types of structures are considered well suited for sites with water depth ranging from 20 to $50 \mathrm{~m}$. Proponents cite the advantages of the jacket structures and refer to low wave loads in comparison to monopoles (jacket structure is very stiff and the area facing wave movement is smaller than that of monopoles), which makes fabrication expertise is widely available in part due to Offshore Oil and Gas industry supply chain. Others cite disadvantages that embrace high initial construction costs, potentially higher maintenance costs and moderately difficult and expensive transportation (Four $\mathrm{C}$ Offshore 2013a).

-Floating platform (Fig. 1e) is the structure that must provide enough buoyancy to support the weight of the turbine and to restrain pitch, wave as well as roll motion within acceptable limits. Therefore, a classification system has been developed and divides all platforms into three general categories based on ballast, mooring lines and buoyancy (Singh et al. 2010).

\section{Case study}

The existing offshore wind farms offer important advantages for aquaculture plans, especially in terms of a lack of major physical constrains, e.g. navigation routes, submarine cables, marine protected areas. Moreover, enhanced current velocity, due to the presence of the piles and air fluxes of the turbines, may increase the environmental suitability of aquaculture plans in these areas. In addition, the transmission of localized depleted water masses or waste material towards near-shore zones can be avoided, excluding a potential impact close to the coast. On the other hand, other environmental constrains (e.g. temperature and variability of salinity, dissolved oxygen concentrations, phytoplankton dynamics) also need to be considered when planning aquaculture activities (Benassai et al. 2011).

Four alternatives to the development of the wind power park in the Baltic Sea near the Lithuanian coast could be considered. The main technical parameters and requirements as well as the preliminary price are provided in Table 1.
Alternative $A_{A}-$ Nordex N80 2.5 MW Wind Turbine (Clean Technology 2010). Nordex offers the N80 $2.5 \mathrm{MW}$ wind turbine. A three-bladed rotor incorporated in the wind turbine measures $80 \mathrm{~m}$ in diameter and offers a swept area of $5026 \mathrm{~m}^{2}$. The rotor operates at speeds ranging from 10.8 to $18.9 \mathrm{rpm}$ and its maximum tolerable tip speed may reach $80 \mathrm{~m} / \mathrm{s}$.

Alternative $A_{B}$ - Vestas V90 3.0 MW Wind Turbine (Vestas 2013). The V90-3.0 MW® is designed to be low weight ensuring easy transportation and installation while reducing foundation costs thanks to its lower load. The nacelle is lighter because its gearbox has an integrated main bearing that eliminates the need for a traditional main shaft.

This turbine delivers exceptional performance, high yield and can be supplied in a variety of hub heights (65$105 \mathrm{~m}$ ) to accommodate site-specific needs. The tower for offshore is designed site-specific and is furthermore protected with a special offshore coating to withstand a harsh environment.

Alternative $A_{C}-G E$ Energy 3.6 MW Wind Turbine (GE Energy 2008). Engineered for high-speed wind sites and harsh marine environment, the $3.6 \mathrm{MW}$ machine features exceptionally robust marine design. The generator and gearbox are supported by elastomeric elements to minimize noise emissions.

Alternative $A_{D}-$ REpower M5 5.0 MW Wind Turbine (Wind Energy Solutions 2013). The REpower 5M has a rated power of 5 megawatt and a rotor of 126 metres in diameter. The $5 \mathrm{M}$ is one of the largest and most powerful wind turbines in the world. The $5 \mathrm{M}$ sets new standards of the economic viability of wind farms, especially in offshore installations.

In order to proceed with the successful application of multi-criteria analysis, it is essential, on the one hand, to determine and examine an adequate number of criteria that will give a representative and complete picture of investigated alternative scenarios, whereas on the other, to calibrate the criteria that will be examined according to their characteristics (Rousis et al. 2008).

In total, five individual criteria have been selected (Project POWER 2008):

-Nominal power of the wind turbine - depends on the type of the wind power plant to be constructed;

-Max power in the area - the park of power plants may be constructed very widely or vice versa. Each separate wind power plant has the required operation area. This way, we may assess power plants in a certain area;

Table 1. The main parameters of wind power plants

\begin{tabular}{lccccc}
\hline \multicolumn{1}{c}{ Manufacturer } & & Nordex & Vestas & GE & REpower \\
\hline Turbine Model & $\mathrm{kW}$ & Nordex N80 & Vestas V90 & GE 3.6 sl & REpower M5 \\
Rated Power & $\mathrm{m}$ & 2500 & 3000 & 3600 & 5000 \\
Rotor Diameter & $\mathrm{m}$ & 100 & 90 & 104 & 126 \\
Hub Height & $\mathrm{m}^{2}$ & 5026 & 105 & 100 & 100 \\
Swept Area & $€$ & 3000000 & 3600000 & 8495 & 12469 \\
Price & $\mathrm{km}^{2}$ & 0.448 & 0.567 & 4320000 & 6000000 \\
Turbine Area & & & & 0.757 & 1.111 \\
\hline
\end{tabular}


- Amount of energy per year - how much energy do wind power plants park produce in reality?

-Investments - the price for developing wind power plants, construction from the idea of design to construction and commissioning. This criterion is crucial for constructing a park, since one wind power plant costs several millions, and the park is developed through many years and the total sum usually is very big;

$-\mathrm{CO}_{2}-$ This is one of the most important criterions indicating why the park of wind power plants is constructed. The situation may vary in each country. Five possible alternative places for constructing wind power plants in the Baltic Sea, near the Lithuanian coast (Fig. 2) can be marked. We will choose the most suitable wind power plant for each of such places in accordance with the criteria introduced above.

\section{Systemized results}

On the basis of the analyzed reports on constructing wind power plants in the sea, the basic calculation data matrices were done, which would help with doing calculations for choosing the type of wind power plants using multicriteria calculation methods.

The basic details necessary for choosing a type of wind power plants in five construction sites are provided in Tables 2-6 (Project POWER 2008).

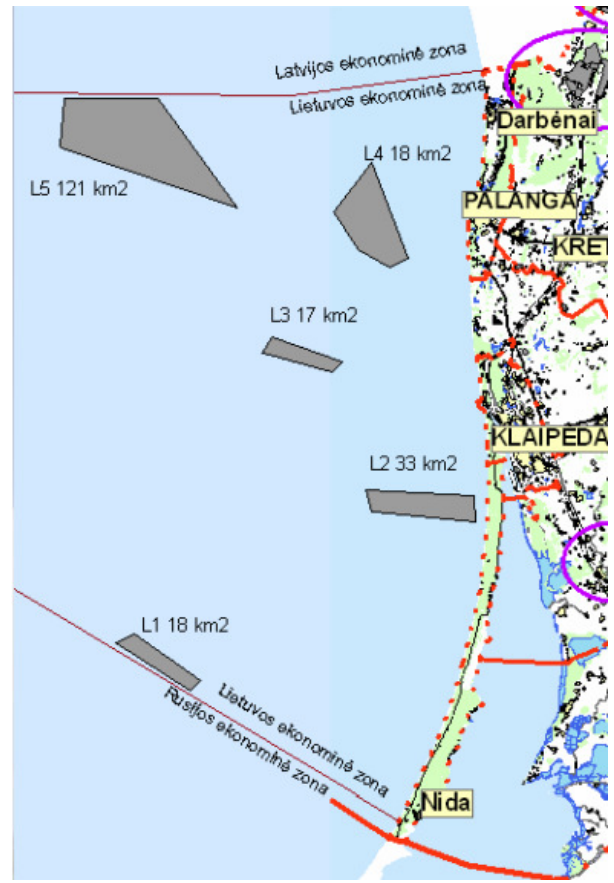

Fig. 2. Possible places for constructing wind power plants in the sea (Klaipeda Science and Technology Park 2010)

Table 2. $L_{1}$ alternative

\begin{tabular}{lccccc}
\hline & & \multicolumn{3}{c}{$\boldsymbol{L}_{\mathbf{1}}$} \\
\hline Manufacturer & & Nordex & Vestas & GE & REpower \\
\cline { 3 - 6 } Turbine model & Nordex N80 & Vestas V90 & GE 3.6 sl & REpower M5 \\
Rated power & $\mathrm{MW}$ & 2.5 & 3.0 & 3.6 & 5.0 \\
Max capacity & $\mathrm{MW}$ & 100 & 96 & 86.4 & 80 \\
Net energy for sale & $10^{3} \mathrm{MWh}$ & 356.4 & 360.2 & 334.0 & 327.7 \\
Capital costs & $10^{6} €$ & 358.969 & 341.100 & 314.184 & 290.447 \\
$\mathrm{CO}_{2}$ & $10^{3} \mathrm{t}$ & 223.10 & 225.50 & 209.05 & 205.13 \\
\hline
\end{tabular}

Table 3. $L_{2}$ alternative

\begin{tabular}{lccccc}
\hline & & \multicolumn{3}{c}{$\boldsymbol{L}_{\mathbf{2}}$} & \multicolumn{2}{c}{ GE } & REpower \\
\cline { 3 - 6 } Manufacturer & & Nordex & Vestas & GE 3.6 sl & REpower M5 \\
\cline { 3 - 6 } Turbine model & $\mathrm{MW}$ & Nordex N80 & Vestas V90 & 3.6 & 5.0 \\
Rated power & $\mathrm{MW}$ & 185 & 3.0 & 158.4 & 150 \\
Max capacity & $10^{3} \mathrm{MWh}$ & 553.2 & 551.0 & 515.4 & 519.3 \\
Net energy for sale & $10^{6} €$ & 466.923 & 427.553 & 384.003 & 348.567 \\
Capital costs & $10^{3} \mathrm{t}$ & 346.32 & 344.95 & 322.61 & 325.06 \\
$\mathrm{CO}_{2}$ & & & &
\end{tabular}

Table 4. $L_{3}$ alternative

\begin{tabular}{|c|c|c|c|c|c|}
\hline \multirow[b]{2}{*}{ Manufacturer } & & \multicolumn{4}{|c|}{$L_{3}$} \\
\hline & & Nordex & Vestas & GE & REpower \\
\hline Turbine model & & Nordex N80 & Vestas V90 & GE $3.6 \mathrm{sl}$ & REpower M5 \\
\hline Rated power & MW & 2.5 & 3.0 & 3.6 & 5.0 \\
\hline Max capacity & MW & 95 & 90 & 79.2 & 75 \\
\hline Net energy for sale & $10^{3} \mathrm{MWh}$ & 310.2 & 310.1 & 280.7 & 282.4 \\
\hline Capital costs & $10^{6} €$ & 259.662 & 240.048 & 210.979 & 192.561 \\
\hline $\mathrm{CO}_{2}$ & $10^{3} \mathrm{t}$ & 194.2 & 194.1 & 175.7 & 176.8 \\
\hline
\end{tabular}


Table 5. $L_{4}$ alternative

\begin{tabular}{lccccc}
\hline & & \multicolumn{3}{c}{$\boldsymbol{L}_{\mathbf{4}}$} & \multicolumn{2}{c}{ GE } & REpower \\
\cline { 3 - 6 } Manufacturer & & Nordex & Vestas & GE 3.6 sl & REpower M5 \\
\cline { 3 - 6 } Turbine model & Nordex N80 & Vestas V90 & 3.6 & 5.0 \\
Rated power & $\mathrm{MW}$ & 2.5 & 3.0 & 226.8 & 215 \\
Max capacity & $10^{3} \mathrm{MWh}$ & 753.1 & 255 & 696.8 & 703.9 \\
Net energy for sale & $10^{6} €$ & 632.161 & 582.7 & 507.556 & 457.270 \\
Capital costs & $10^{3} \mathrm{t}$ & 471.4 & 477.5 & 436.2 & 440.6 \\
$\mathrm{CO}_{2}$ & & & &
\end{tabular}

Table 6. $L_{5}$ alternative

\begin{tabular}{lccccc}
\hline & & \multicolumn{3}{c}{$\boldsymbol{L}_{\mathbf{5}}$} & \multicolumn{2}{c}{ GE } & REpower \\
\cline { 3 - 6 } Manufacturer & & Nordex & Vestas & GE 3.6 sl & REpower M5 \\
\cline { 3 - 6 } Turbine model & $\mathrm{MW}$ & Nordex N80 & Vestas V90 & 3.6 & 5.0 \\
Rated power & $\mathrm{MW}$ & 675 & 3.0 & 576 & 545 \\
Max capacity & $10^{3} \mathrm{MWh}$ & 2438.1 & 2428.2 & 2255.7 & 2262.1 \\
Net energy for sale & $10^{6} €$ & 1596.710 & 1462.0126 & 1290.070 & 1160.311 \\
Capital costs & $10^{3} \mathrm{t}$ & 1526.3 & 1520.0 & 1412.1 & 1416.1 \\
$\mathrm{CO}_{2}$ & & & & &
\end{tabular}

Table 7. Nine-point scale of a pairwise comparison (Saaty 1980)

\begin{tabular}{ll}
\hline \multicolumn{1}{c}{ Intensity of importance } & \multicolumn{1}{c}{ Definition } \\
\hline 1 & Criteria $i$ and $j$ are of equal importance \\
3 & Criterion $i$ is moderately more important than criterion $j$ \\
5 & Criterion $i$ is strongly more important than criterion $j$ \\
7 & Criterion $i$ is very strongly or demonstrably more important than criterion $j$ \\
9 & Criterion $i$ is extremely more important than criterion $j$ \\
$2,4,6,8$ & Compromise values between two adjacent judgments \\
Reciprocals & If activity $i$ has one of the nonzero numbers assigned to it when compared with activity $j$, then, $j$ \\
nonzero & has the reciprocal value when compared with $i$ \\
\hline
\end{tabular}

Table 8. Pair-wise comparisons considering criteria

\begin{tabular}{cccccccc}
\hline & \multicolumn{7}{c}{ Expert 1 } \\
\cline { 2 - 8 } & $\boldsymbol{X}_{\mathbf{1}}$ & $\boldsymbol{X}_{\mathbf{2}}$ & $\boldsymbol{X}_{\mathbf{3}}$ & $\boldsymbol{X}_{\mathbf{4}}$ & $\boldsymbol{X}_{\mathbf{5}}$ & Products & $\boldsymbol{w}_{\mathbf{1}}$ \\
\cline { 2 - 8 }$X_{1}$ & 1 & 4 & 0.167 & 1 & 6 & 1.320 & 0.195 \\
$X_{2}$ & 0.25 & 1 & 0.2 & 0.333 & 4 & 0.582 & 0.086 \\
$X_{3}$ & 6 & 5 & 1 & 1 & 5 & 2.724 & 0.403 \\
$X_{4}$ & 1 & 3 & 1 & 1 & 6 & 1.783 & 0.264 \\
$X_{5}$ & 0.167 & 0.25 & 0.2 & 0.667 & 1 & 0.354 & 0.052 \\
\hline
\end{tabular}

Table 9. Criterion weights

\begin{tabular}{llllllllllll}
\hline & Exp. 1 & Exp. 2 & Exp. 3 & Exp. 4 & Exp. 5 & Exp. 6 & Exp. 7 & Exp. 8 & Exp. 9 & Exp. 10 & Average \\
\hline$X_{1}$ & 0.195 & 0.261 & 0.240 & 0.086 & 0.171 & 0.087 & 0.162 & 0.088 & 0.181 & 0.112 & 0.158 \\
$X_{2}$ & 0.086 & 0.207 & 0.292 & 0.330 & 0.271 & 0.191 & 0.202 & 0.170 & 0.154 & 0.162 & 0.206 \\
$X_{3}$ & 0.403 & 0.089 & 0.158 & 0.196 & 0.194 & 0.300 & 0.343 & 0.385 & 0.308 & 0.394 & 0.277 \\
$X_{4}$ & 0.264 & 0.390 & 0.162 & 0.345 & 0.207 & 0.366 & 0.254 & 0.304 & 0.315 & 0.290 & 0.290 \\
$X_{5}$ & 0.052 & 0.054 & 0.148 & 0.043 & 0.158 & 0.056 & 0.039 & 0.054 & 0.043 & 0.043 & 0.069 \\
\hline
\end{tabular}

\section{Determination of criteria weights}

The decision has been made using the derived weight $w$ of evaluative criteria (Saaty 1980). The experiments conducted by Saaty shows that most individuals cannot compare more than seven, plus/minus two criteria (Table 7). follows:

The AHP initial pair-wise comparison matrix is as

$$
A=\left(x_{i j}\right)=\left[\begin{array}{cccc}
1 & \frac{w_{1}}{w_{2}} & \cdots & \frac{w_{1}}{w_{m}} \\
\frac{w_{2}}{w_{1}} & 1 & \cdots & \frac{w_{2}}{w_{m}} \\
\vdots & \vdots & \ddots & \vdots \\
\frac{w_{m}}{w_{1}} & \frac{w_{m}}{w_{2}} & \cdots & 1
\end{array}\right],
$$




$$
\begin{gathered}
x_{i j}=1, x_{i j}=\frac{1}{x_{i j}}, x_{i j} \neq 0 . \\
w_{j}=\left(\prod_{k=1}^{p} y_{j k}\right)^{\frac{1}{p}}, j=\overline{1, n}, k=\overline{1, p} .
\end{gathered}
$$

Also, the consistency index and consistency ratio should be calculated (Saaty 1980).

Ten experts prepared different pair-wise comparison matrixes the examples of which are shown in Table 8.

The weights of the criteria of the fuzzy group have been established and presented in Table 9 .

\section{Calculation method}

A multi-person decision-making problem is defined as a decision situation in which an alternative to the given problem should be chosen. WASPAS method for finding a solution to the problem has been selected. The initial information on the problem has been provided by different people or experts.

Zavadskas et al. (2012) proposed aggregating WSM (Weighted Sum Model) and WPM (Weighted Product Model) methods. WASPAS (Weighted Aggregates Sum Product Assessment) method was developed. The optimization of the weighted aggregated function has been suggested, which allows reaching the highest accuracy of measurement. Zavadskas et al. (2013) used WASPAS and MOORA (Multiple Objective Optimization on the basis of Ratio Analysis) as well as MULTIMOORA (MOORA plus Full Multiplicative Form) methods for the multiple criteria assessment of building designs.

Hashemkhani Zolfani et al. (2013) applied Stepwise Weight Assessment Ratio Analysis (SWARA) and WASPAS methods for evaluating shopping mall sites in Tehran.

Dejjus and Antuchevičienè (2013) suggested employing Multiple Criteria Decision Making (MCDM) technique for assessing and selecting appropriate solutions to occupational safety and proposed formulating considered alternatives from typical solutions to ensuring their quality and then applying the entropy method for determining relative significance to evaluation criteria. Finally, WASPAS method for ranking alternatives has been used.

Staniūnas et al. (2013) referred to multi-criteria decision making method WASPAS and to the scenarios evaluating the modernization of multi-dwelling houses.

Šiožinytė and Antuchevičiené (2013) presented a model for improving daylight in the reconstructed building and simultaneously analysing the process of saving the features of vernacular architecture, which is based on WASPAS method.

Chakraborty and Zavadskas (2014) explored WASPAS method as an effective MCDM tool while solving eight manufacturing decision making problems. The method has been observed to find out the capability of accurately ranking alternatives in all considered selection problems.
Normally, information can be represented by any of the following three preference structures (Herrera et al. 2001):

- As a preference ordering alternatives. In this case, alternatives are ordered from the best to worst without any other additional information;

- As a utility function. In this case, an expert gives a real valuation (a physical or monetary value) on each alternative, i.e. the function that associates each alternative with a real number. This indicates the performance of that alternative according to that point of view;

-As a preference relation. This is the most usual case because most procedures for decision-making problems are based on a pair comparison in the sense that processes are linked to some degree of the credibility of the preference of any alternative over another. below.

The description of WASPAS method is presented

First, the initial decision-making matrix is formed. Next, a step - initial decision-making matrix is normalized as:

$$
\bar{x}_{i j}=\frac{x_{i j}}{\max _{i} x_{i j}}
$$

for criteria that must be maximized, and:

$$
\bar{x}_{i j}=\frac{\min _{i} x_{i j}}{x_{i j}}
$$

for criteria that must be minimized.

Some multi-criteria utility functions are additive and some are multiplicative. Therefore, a proposal to integrate both additive and multiplicative utility functions to one has been made. For this reason, the applied function is as follows:

$$
K_{i}=\lambda \sum_{j=1}^{n} \bar{x}_{i j} w_{j}+(1-\lambda) \prod_{j=1}^{n} \bar{x}_{i j}^{w_{j}},
$$

$\lambda$ is used 0.5 .

\section{Summary of calculations}

Following the calculations done employing WASPAS method (Table 10), it has been determined that the best option of assessing the types of wind power plants situated in different possible places of construction is the $4^{\text {th }}$ one, which is Repower M5 5.0 MW Wind Turbine (Fig. 3).

Considering the suggested options, this is the most powerful $(5 \mathrm{MW})$ wind power plant having the biggest rotor of $126 \mathrm{~m}$ in diameter and the average height of $100 \mathrm{~m}$.

Due to its modular structure and logistical flexibility, the $5 \mathrm{M}$ is suitable for onshore and offshore installation. The offshore version is specifically designed for withstanding extreme environmental conditions. This includes, for example, the redundancy of key components to guarantee 
Table 10. Solution results

\begin{tabular}{ccccccccccc}
\hline & \multicolumn{2}{c}{$L_{1}$ Alternative } & \multicolumn{2}{c}{$L_{2}$ Alternative } & \multicolumn{2}{c}{$L_{3}$ Alternative } & \multicolumn{2}{c}{$L_{4}$ Alternative } & \multicolumn{2}{c}{$L_{5}$ Alternative } \\
\cline { 2 - 10 } & $K_{i}$ & Rank & $K_{i}$ & Rank & $K_{i}$ & Rank & $K_{i}$ & Rank & $K_{i}$ & Rank \\
\hline$A_{\mathrm{A}}$ & 0.8463 & 4 & 0.8311 & 4 & 0.8278 & 4 & 0.8204 & 4 & 0.8246 & 4 \\
$A_{\mathrm{B}}$ & 0.8733 & 3 & 0.8595 & 3 & 0.8558 & 3 & 0.8525 & 3 & 0.8538 & 3 \\
$A_{\mathrm{C}}$ & 0.8816 & 2 & 0.8786 & 2 & 0.8680 & 2 & 0.9002 & 2 & 0.8739 & 2 \\
$A_{\mathrm{D}}$ & 0.9320 & 1 & 0.9420 & 1 & 0.9295 & 1 & 0.9359 & 1 & 0.9386 & 1 \\
\hline
\end{tabular}
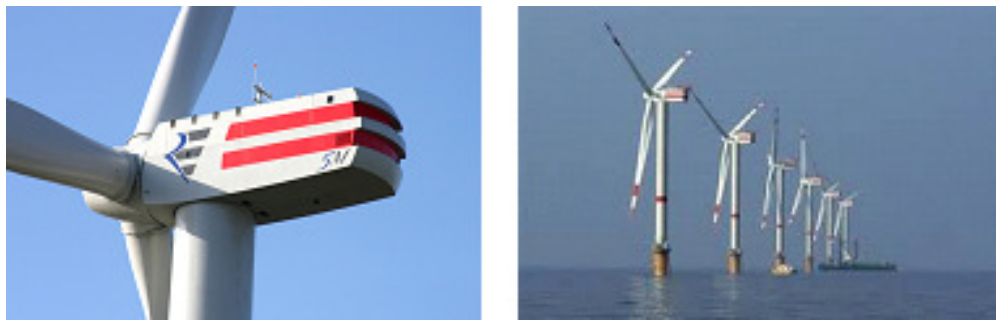

Fig. 3. REpower M5 5.0 MW Wind Turbine (Wikimedia commons 2012)

maximum availability, effective protection against corrosion and a permanent monitoring system (Wind energy solutions 2013).

\section{Conclusions}

Recently, wind energy has become more and more valued. Although most of the constructed wind power plants have been constructed on land, those erected in the sea are taking the lead nowadays.

The construction sequence of the wind turbine should be as follows: $A_{\mathrm{D}} \succ A_{\mathrm{C}} \succ A_{\mathrm{B}} \succ A_{\mathrm{A}}$.

Although investments in the production of wind energy in the sea are much bigger and construction is incomparably more complicated than investments and construction on land, the possibilities of payoff are significantly higher because the wind in the sea is much stronger.

Calculations have been done applying WASPAS method and show that the best type of the wind power plant suitable for all options is REpower M5 5.0 MW Wind Turbine.

\section{References}

Benassai, G.; Stenberg, C.; Christoffersen, M.; Mariani, P. 2011. A sustainability index for offshore wind farms and open water aquaculture, in Proc. of the $2^{\text {nd }}$ International Conference on Physical Coastal Processes, Management and Engineering 149: 3-14. http://dx.doi:10.2495/CP110011

Carey, J. M. 2002. Guyed support structures for offshore wind turbines, in Proc. of the $2^{\text {nd }}$ Symposium Offshore Wind Energy - Construction and Environmental Aspects, September, 2002, Hannover, Germany. 7 p.

Chakraborty, S.; Zavadskas, E. K. 2014. Applications of WASPAS method in manufacturing decision making, Informatica 25(1): 1-20.

Clean Technology. 2010. Nordex N80 2.5 MW Wind Turbine from Nordex [online], [cited 10 January 2014]. Available from Internet: http://www.azocleantech.com/news.aspx?newsID=10656

Collu, M.; Brennan, F. P.; Patel, M. H. 2012. Nova project: lessons learnt during the conceptual phase of the design of a floating support structure for an offshore vertical axis wind turbine, in Proc. of the $31^{\text {st }}$ International Conference on Ocean, Offshore and Arctic Engineering 7: 637-648. http://dx.doi:10.1115/OMAE2012-84232

Dejus, T.; Antuchevičienè, J. 2013. Assessment of health and safety solutions at a construction site, Journal of Civil Engineering and Management 19(5): 728-737. http://dx.doi:10.3846/13923730.2013.812578

First for Technology and Innovation. 2013. Wind energy gets serial [online], [cited 18 January 2014]. Available from Internet: http://www.theengineer.co.uk/in-depth/the-bigstory/wind-energy-gets-serial/1012449.article

Four C Offshore. 2013a. Jacket or lattice structures [online], [cited 15 January 2014]. Available from Internet: http://www.4coffshore.com/windfarms/jacket-or-latticestructures-aid271.html

Four C Offshore. 2013b. Tripod support structures [online], [cited 15 January 2014]. Available from Internet: http://www.4coffshore.com/windfarms/tripod-supportstructures-aid273.html

Gamboa, G.; Munda, G. 2007. The problem of wind farm location: a social multi-criteria evaluation framework, Energy Policy 35(3): 1564-1583. http://dx.doi:10.1016/j.enpol.2006.04.021

GE Energy. 2008. 3.6MW Offshore series wind turbine [online], [cited 7 January 2014]. Available from Internet: http://www.ceoe.udel.edu/windpower/resources/ge_36_br ochure_new.pdf.

Gipe, P. 2004. Wind power, Wind Engineering 28(5): 629-631. http://dx.doi:10.1260/0309524043028145

Green, R.; Vasilakos, N. 2011. The economics of offshore wind, Energy Policy 39(2): 496-502. http://dx.doi.org/10.1016/j.enpol.2010.10.011

Hashemkhani Zolfani, S.; Aghdaie, M. H.; Derakhti, A.; Zavadskas, E. K.; Varzandeh, M. H. M. 2013. Decision making on business issues with foresight perspective; an application of new hybrid MCDM model in shopping mall locating, Expert Systems with Applications 40(17): 71117121. http://dx.doi:10.1016/j.eswa.2013.06.040

Herrera, F.; Herrera-Viedma, E.; Chiclana, F. 2001. Multiperson decision-making based on multiplicative preference relations, European Journal of Operational Research 129(2): $372-385$.

http://dx.doi.org/10.1016/S0377-2217(99)00197-6 
Hessami, A.; Campbell, H.; Sanguinetti, C. 2011. A feasibility study of hybrid wind power systems for remote communities, Energy Policy 39(2): 877-886. http://dx.doi.org/10.1016/j.enpol.2010.11.011

Houlsby, G. T.; Byrne, B. W. 2000. Suction caisson foundations for offshore wind turbines and anemometer masts, Wind Engineering 24(4): 249-255. http://dx.doi:10.1260/0309524001495611

Kaya, T.; Kahraman, C. 2010. Multicriteria renewable energy planning using an integrated fuzzy VIKOR \& AHP methodology: the case of Istanbul, in Proc. of the $7^{\text {th }}$ International Conference on Sustainable Energy Technologies 35(6): 2517-2527. http://dx.doi:10.1016/j.energy.2010.02.051

Katinas, V.; Marčiukaitis, M.; Markevičius, A. 2009. Current situation of the wind energy use and investigation of wind resources in the coastal region of the Baltic Sea in Lithuania, Renewable and Sustainable Energy Reviews 13(1): 201-207. http://dx.doi:10.1016/j.rser.2007.06.012

Khan, S. A.; Rehman, S. 2012. On the use of unified And-Or fuzzy aggregation operator for multi-criteria decision making in wind farm design process using wind turbines in $500 \mathrm{~kW}-750 \mathrm{~kW}$ range, in Proc. of the International Conference on Fuzzy Systems, (FUZZ-IEEE), 10-15 June, 2012, Brisbane, Australia, 1762-1768. http://dx.doi:10.1109/FUZZ-IEEE.2012.6251306

Kim, J.-Y.; Oh, K.-Y.; Kang, K.-S.; Lee, J.-S. 2013. Site selection of offshore wind farms around the Korean Peninsula through economic evaluation, Renewable Energy 54: 189195. http://dx.doi:/10.1016/j.renene.2012.08.026

Klaipeda Science and Technology Park. 2010. Vejo jégainiu pletra vakaru Lietuvoje [Development of wind turbines in west side of Lithuania] [online], [cited 12 January 2014]. Available from Internet:

http://www.kmtp.lt/uploads/Renginiai/Inotinkloseminaras 100226/VejojegainiupletraLietuvoje.pdf (in Lithuanian).

Kurian, V. J.; Narayanan, S. P.; Ganapathy, C. 2009. Towers for offshore wind turbines, in Proc. of the $10^{\text {th }}$ Asian International Conference on Fluid Machinery, 21-23 October, Kuala Lumpur, Malaysia, 475-488. http://dx.doi.org/10.1063/1.3464894

Lee, A. H. I.; Chen, H. H.; Kang, H. Y. 2009. Multi-criteria decision making on strategic selection of wind farms, Renewable Energy 34(1): 120-126. http://dx.doi:10.1016/j.renene.2008.04.013

Lee, A. H. I.; Hung, M.-C.; Kang, H.-Y.; Pearn, W. L. 2012. A wind turbine evaluation model under a multi-criteria decision making environment, Energy Conversion and Management 64: 289-300. http://dx.doi:10.1016/j.enconman.2012.03.029

Lemming, J. K.; Morthorst, P. E.; Clausen, N.-E. 2008. Offshore wind power. Experiences. Potential and key issues for development. Riso National Laboratory for Sustainable Energy, Denmark. 26 p.

Leung, D. Y. C.; Yang, Y. 2012. Wind energy development and its environmental impact: a review, Renewable and Sustainable Energy Reviews 16(1): 1031-1039. http://dx.doi:10.1016/j.rser.2011.09.024

Lozano-Minguez, E.; Kolios, A. J.; Brennan, F. P. 2011. Multicriteria assessment of offshore wind turbine support structures, Renewable Energy 36(11): 2831-2837. http://dx.doi:10.1016/j.renene.2011.04.020

Maeda, T.; Yokota, T.; Shimizu, Y.; Adachi, K. 2004. Wind tunnel study of the interaction between two horizontal ax- is wind turbines, Wind Engineering 28(2): 197-212.

http://dx.doi:10.1260/0309524041211396

Markevičius, A.; Katinas, V.; Marčiukaitis, M. 2007. Wind energy development policy and prospects in Lithuania, Energy Policy 35(10): 4893-4901.

http://dx.doi:10.1016/j.enpol.2007.03.026

Martin, H.; Spano, G.; Küster, J. F.; Collu, M.; Kolios, A. J. 2013. Application and extension of the TOPSIS method for the assessment of floating offshore wind turbine support structures, Ships and Offshore Structures 8(5): 477487. http://dx.doi:10.1080/17445302.2012.718957

Malhotra, S. 2010. Design and construction considerations for offshore wind turbine foundations in North America, in Proc. of the GeoFlorida 2010, Advances in Analysis, Modeling \& Design, 20-24 February, 2010, Florida, USA, 1533-1542. http://dx.doi:10.1061/41095(365)155

Offshore Wind Collaborative Organizing. 2005. A framework for offshore wind energy development in the United States, Washington. US Department of Energy. 34 p.

Project POWER. 2008. Baltic offshore energy cluster [online], [cited 10 January 2014]. Available from Internet: http://www.bosec.lt/eco/eco_lt.html

Wind Energy Solutions. 2013. REpower systems [online], [cited 20 December 2013]. Available from Internet: http://www.repower.de/fileadmin/download/produkte/RE PP_5M_uk

Rousis, K.; Moustakas, K.; Malamis, S.; Papadopoulos, A.; Loizidou, M. 2008. Multi-criteria analysis for the determination of the best WEEE management scenario in $\mathrm{Cy}-$ prus, Waste Management 28(10): 1941-1954. http://dx.doi.org/10.1016/j.wasman.2007.12.001

Saaty, T. L. 1980. The Analytic Hierarchy Process: planning, priority setting, resource allocation. Mcgraw-Hill. $287 \mathrm{p}$.

Singh, B.; Mistri, B.; Patel, R. 2010. Comparison of foundation systems for offshore wind turbine installation. Institutional repository of College of Engineering, Trivandrum, India [online], [cited 10 January 2014]. Available from Internet:

http://117.211.100.42:8180/jspui/bitstream/123456789/10 57/1/CEGE04.pdf

Soderholm, P.; Pettersson, M. 2011. Offshore wind power policy and planning in Sweden, Energy Policy 39(2): 518525. http://dx.doi.org/10.1016/j.enpol.2010.05.065

Sovacool, B. K.; Lindboe, H. H.; Odgaard, O. 2008. Is the Danish wind energy model replicable for other countries?, The Electricity Journal 21(2): 27-38. http://dx.doi.org/10.1016/j.tej.2007.12.009

Staniūnas, M.; Medineckienė, M.; Zavadskas, E. K.; Kalibatas, D. 2013. To modernize or not: Ecological - economical assessment of multi-dwelling houses modernization, Archives of Civil and Mechanical Engineering 13(1): 88-98. http://dx.doi:10.1016/j.acme.2012.11.003

Structural Engineers Club. Jüriniu vejo jègainiu projektavimas. 2 dalis [Design of marine wind turbines. Part 2]. 2014. [online], [cited 18 January 2014]. Available from Internet: http://www.konstruktoriu-klubas.lt/index.php/lt/2012-0320-12-16-07/specialieji-statiniai/94-juriniu-vejo-jegainiuprojektavimas-2-dalis

Šiožinytė, E.; Antuchevičienè, J. 2013. Solving the problems of daylighting and tradition continuity in a reconstructed vernacular building, Journal of Civil Engineering and Management 19(6): 873-882.

http://dx.doi:10.3846/13923730.2013.851113 
Van Bussel, G.; Zaaijer, M. 2001. Reliability, availability and maintenance aspects of large-scale offshore wind farms: a concepts study, in Proc. of the Marine Renewable Energies Conference, 2001, 113(1): 119-126.

Van Haaren, R.; Fthenakis, V. 2011. GIS-based wind farm site selection using spatial multi-criteria analysis (SMCA): evaluating the case for New York State, Renewable and Sustainable Energy Reviews 15(7): 3332-3340. http://dx.doi:10.1016/j.rser.2011.04.010

Vestas. 2013. V90-3.0 MW at a glance [online], [cited 10 January 2014]. Available from Internet: http://www.vestas.com/en/products_and_services/turbines /v90-3_0_mw

Wikimedia commons. 2012. Repower $5 M$ [online], [cited 8 January 2014]. Available from Internet: http://commons.wikimedia.org/wiki/File:Repower_5M.jpg
Zavadskas, E. K.; Antucheviciene, J.; Saparauskas, J.: Turskis, Z. 2013. MCDM methods WASPAS and MULTIMOORA: verification of robustness of methods when assessing alternative solutions, Economic Computation \& Economic Cybernetics Studies \& Research 47(2): 5-20.

Zavadskas, E. K.; Turskis, Z.; Antucheviciene, J.; Zakarevicius, A. 2012. Optimization of Weighted Aggregated Sum Product Assessment, Elektronika ir elektrotechnika (6): 3-6. http://dx.doi:oi.org/10.5755/j01.eee.122.6.1810

Zhixin, W.; Chuanwen, J.; Qian, A.; Chengmin, W. 2009. The key technology of offshore wind farm and its new development in China, Renewable and Sustainable Energy Reviews 13(1): 216-222. http://dx.doi:10.1016/j.rser.2007.07.004

Vygantas BAGOČIUS. PhD student at the Department of Construction Technology and Management of Vilnius Gediminas Technical University, Vilnius, Lithuania. Master of Construction Engineering, Kaipeda University, 2010. Research interests: building technologies, construction management, multiple criteria analysis and decision-making theories.

Edmundas Kazimieras ZAVADSKAS. PhD, DSc, h.c.multi. Prof., Head of the Department of Construction Technology and Management at Vilnius Gediminas Technical University, Lithuania. Senior Research Fellow at the Research Institute of Internet and Intelligent Technologies. A member of Lithuanian and several foreign Academies of Sciences. Doctore Honoris Causa from Poznan, Saint-Petersburg and Kiev universities. The Honorary International Chair Professor in the National Taipei University of Technology. A member of international organizations; a member of steering and programme committees at many international conferences; a member of editorial boards of several research journals; the author and co-author of more than 400 papers and a number of monographs in Lithuanian, English, German and Russian. Editor-in-Chief of journals Technological and Economic Development of Economy and Journal of Civil Engineering and Management. Research interests: building technology and management, decision-making theory, automation in design and decision support systems.

Zenonas TURSKIS. Prof. Dr of Technical Sciences, Senior Research Fellow at the Laboratory of Construction Technology and Management, Vilnius Gediminas Technical University. Research interests: building technology and management, decision-making theory, computer-aided automation in design, expert systems. 